\title{
PHYSICOCHEMICAL PROPERTIES OF HONEY PRODUCED IN THE HOMESHA DISTRICT OF WESTERN ETHIOPIA
}

\author{
Sisay Gobessa', Eyassu Seifu', Amsalu Bezabih \\ ${ }^{1}$ Department of Animal and Fish Resource Development, \\ Bureau of Agriculture and Rural Development, \\ Benishangul Gumuz Regional State, P.O.Box 30, Assosa, Ethiopia. \\ ${ }^{2}$ Department of Animal Sciences, Haramaya University, P.O.Box 287, Haramaya campus, Ethiopia. \\ ${ }^{3}$ Honeybee Research Program, Holetta Agricultural Research Center, P.O.Box 22, Holetta, Ethiopia. \\ e-mail: eyassu_seifu@yahoo.com
}

Received 24 October 2011; accepted 08 May 2012

$\mathrm{S}$ u m m a r y

This study was conducted to characterize honey produced in the Homesha district in Western Ethiopia. The effects of location and hive type on the quality of honey produced in the area were assessed. A total of 20 honey samples were collected from four locations in the district. The overall mean $( \pm \mathrm{SD})$ contents of reducing sugars, sucrose, $\mathrm{pH}$, moisture, ash, hydroxymethylfurfural, acidity and water-insoluble solids of the honey samples analyzed were $65 \pm 3.02 \%, 6.1 \pm 3.4 \%, 4.02 \pm 0.26$, $16.4 \pm 1.07 \%, 0.17 \pm 0.07 \%, 1.8 \pm 0.24 \mathrm{mg} / \mathrm{kg}, 23.9 \pm 7.4 \mathrm{meq} / \mathrm{kg}$ and $0.09 \pm 0.14 \%$, respectively. The sucrose content of honey samples purchased from the market was significantly higher $(p<0.05)$ than the sucrose contents of honey samples collected from other locations. Hive type significantly $(\mathrm{p}<0.05)$ influenced the contents of moisture, HMF and water-insoluble solids of honey samples. It can be concluded that honey produced in the Homesha district is of good quality and can meet the national and international market demands.

Keywords: honey, chemical composition, physical property, quality, Homesha, Ethiopia.

\section{INTRODUCTION}

Beekeeping is an important agricultural activity in Ethiopia. Owing to its varied ecological and climatic conditions, the country is home to some of the most diverse flora and fauna in Africa. This diversity makes it highly suitable for sustaining a large number of bee colonies (Adgaba, 2007). The country has the largest bee population in Africa. There are over 10 million bee colonies, out of which about 7.5 million are confined in hives and the remaining exist in the forest (Adgaba, 2007). This makes the country one of the largest honey producers and the third largest beeswax producer worldwide. Ethiopian honey production accounts for approximately $2.5 \%$ of world production and $21.7 \%$ of African honey production (MoARD, 2007).
The composition and quality of honey are greatly influenced by geographical and environmental factors (J ones et al., 2011). The quality and properties of honey are related to honey maturity, the production methods, climatic conditions, processing and storage conditions as well as nectar sources of the honey (Persano Oddo and Piro, 2004; Szczęsna et al., 2011; Waś et al., 2011a, 2011b). However, quality and composition of honey are negatively affected by factors such as overfeeding sucrose and sucrose variants, harvesting prior to maturity, and inappropriate storage conditions (Oddo and Bogdanov, 2004; Rybak-Chmielewska et al., 2006). The type of hive used and the methods of collection and storage of honey play a vital role in determining the quality of honey (Negera, 2005). Despite the large number of honeybee colonies and diversified honey 
floral resources, production of honey is far below its potential in Ethiopia. This may be due to the fact that the apiculture sector has received little research and development attention, and because honey produced in the different agro-ecologies of the country has not been characterized to date. The Homesha district has a good chance of developing its beekeeping and honey production because a large proportion of the land in the district is covered with natural vegetation such as Cordia africana, Ficus spp. and Eucalyptus spp. Besides, flowers of many annual (maize, haricot bean, Guizotia abyssinica and sesame) and perennial (cassava, coffee, chat) crops and fruits (mango, papaya, banana, orange, lemon and avocado) serve as forage sources for the honeybees. The district produces large amounts of honey every year and honey production is one of the major income sources for farmers in the area. Different non-governmental organizations operate in the area and are involved in the development of the apicultural sector in the district. Farmers are provided with modern hives, honeybee equipment, and training on the subject of beekeeping.

To date, no study has been conducted to assess the physicochemical properties of honey produced in the Homesha district. In order to produce and improve the quality of honey that meets the demands of national and international markets and quality criteria (QSAE, 2005; Codex Alimentarius 2001, Council Directive, 2002), information about the quality of honey produced in the area is important. The objective of this study was, therefore, to characterize honey produced in the Homesha district of the Benishangul Gumuz Regional State in Western Ethiopia.

\section{MATERIALS AND METHODS}

Out of the 11 rural villages in the Homesha district, five villages namely Bamado and Kuburhamsa (dominated by natural vegetation mainly Cordia africana, Ficus spp. and Eucalyptus spp.) Tumet and Algala (dominated by mango plant) and Tsoearumale (dominated mainly by the crops maize, sorghum, haricot bean, Guizotia abyssinica and sesame) were selected purposively for honey sample collections based on the distribution and abundance of honeybee colonies. In addition, honey samples were also collected from the Homesha market.

A total of 20 honey samples were collected from the four locations in the district. Six samples were obtained from natural vegetation dominated areas, six samples were obtained from mango dominated areas, three samples were obtained from crop dominated areas and five honey samples were purchased from the local market. Among these, ten samples were obtained from modern hives and five were obtained from traditional hives. In the study area, two major types of bee hives are used; traditional and modern hives. Traditional (fixed comb) hives are the most commonly used hive types in the area and are made from locally available materials such as bamboo, elephant grass and cow dung. These hives are usually kept on tree trunks around homesteads or in the forest. Although recently introduced by non-governmental organizations, modern (moveable-frame) hives have now become popular in the study area. Moveable-frame hives are expensive and labor intensive compared to traditional hives.

The honey samples were analyzed for their physicochemical properties following standard procedures. The water-insoluble solids content, moisture, hydroxymethylfurfural, ash, acidity, and $\mathrm{pH}$ of the honey samples were analyzed at the Quality and Standards Authority of Ethiopia. Reducing sugars and sucrose were analyzed at the Ethiopian Health and Nutrition Research Institute laboratory.

The moisture content of the honey samples was determined according to the procedures of the Quality and Standards Authority of Ethiopia (QSAE, 2005). The refractive index of the honey samples was determined using a refractometer (Leica Abbe Mark II Plus Refractometer). The refractive index values of the honey samples were converted to moisture 
content using the conversion table reported by White et al. (1962).

The content of reducing sugar in the honey samples was determined by the modified procedure of Lane and Eynon (1923). The procedure involved the reduction of Soxhlet's modification of Fehling's solution by titration with copper sulphate at the boiling point $\left(60^{\circ} \mathrm{C}\right)$ against a solution of reducing sugars in honey, using methylene blue as an internal indicator (Pearson, 1971). The sucrose content of the honey samples was determined according to Pearson (1971). Titration was done following a procedure similar to that for the determination of reducing sugars.

Total ash content of the honey samples was determined by calcinations of $5 \mathrm{~g}$ of honey, overnight, in a muffle furnace at $550^{\circ} \mathrm{C}$ until a constant mass was attained (Bogdanov, 2002). The residue was then weighed after cooling to room temperature, in a desiccator. Total ash content (\%) was calculated according to QSAE (2005).

The free acidity of honey samples was determined according to QSAE (2005). Ten grams of honey sample was dissolved in $75 \mathrm{ml}$ of carbon-dioxide-free distilled water in a $250 \mathrm{ml}$ beaker and stirred with a magnetic stirrer. The solution was titrated with $0.1 \mathrm{M}$ of sodium hydroxide $(\mathrm{NaOH})$ solution to a final $\mathrm{pH}$ of 8.50 .

The $\mathrm{pH}$ of the honey samples was determined according to Pearson (1971). Ten grams of the honey sample were dissolved in $75 \mathrm{ml}$ of carbon-dioxide-free water in a $250 \mathrm{ml}$ beaker. The solution was stirred with a magnetic stirrer. Then the $\mathrm{pH}$ was measured with a $\mathrm{pH}$ Meter (WTW inolab, GmbH, Germany) that was calibrated using $\mathrm{pH} 4.0$ and 7.0 buffers.

Hydroxymethylfurfural (HMF) content of the honey samples was determined by measuring the absorbance of HMF at $284 \mathrm{~nm}$ using a UV Spectrophotometer (Spectrophotometer UV/VIS Series 284-336, Biochrom, UK) according to Bogdanov (2002).

The water-insoluble solids content of the honey samples was determined according to the QSAE (2005).

Each of the honey samples was analyzed in duplicate for the parameters considered.

Data generated was analyzed by the analysis of variance technique using the General Linear Model for unbalanced data of SAS (2002) version 9. Comparison of honey quality was done between honey samples obtained from the four locations and between honey samples obtained from modern and traditional hives. Duncan's multiple range test was used for mean separation when ANOVA showed difference between means. Significant differences were declared at the $5 \%$ significance level.

\section{RESULTS AND DISCUSSION}

The minimum, maximum, and average moisture contents of the honey samples analyzed in the present study are indicated in Table 1. The overall mean moisture content of the study area's honey was lower than the country's average $(20.6 \%)$

Table 1 .

Physicochemical properties of honey produced in the Homesha district $(\mathrm{n}=20)$

\begin{tabular}{||c|c|c||}
\hline Parameters & Range & Mean \pm SD \\
\hline Moisture (\% by mass) & $15.01-18.16$ & $16.4 \pm 1.07$ \\
\hline Total ash (\% by mass) & $0.014-0.31$ & $0.17 \pm 0.07$ \\
\hline Acidity (meq/kg) & $18.01-36.54$ & $23.9 \pm 7.4$ \\
\hline $\mathrm{pH}$ & $3.52-4.46$ & $4.02 \pm 0.26$ \\
\hline $\mathrm{HMF}(\mathrm{mg} / \mathrm{kg})$ & $0.5-3.2$ & $1.8 \pm 0.24$ \\
\hline Water-insoluble matter (g/100 $\mathrm{g})$ & $0.01-0.46$ & $0.09 \pm 0.14$ \\
\hline Reducing sugars $(\%$ by mass) & $62.0-71.0$ & $65 \pm 3.02$ \\
\hline Sucrose (\% by mass) & $4.4-12$ & $6.1 \pm 3.4$ \\
\hline
\end{tabular}

$\mathrm{HMF}=$ hydroxymethylfurfural; $\mathrm{n}=$ number of samples; $\mathrm{SD}=$ standard deviation. 
for moisture content of honey reported by Adgaba (1999). According to honey standards set by the Ethiopian Quality and Standards Authority, the moisture content of the study area's honey falls under the Grade 'A' category (QSAE, 2005). The maximum acceptable limit for moisture content of Ethiopian honey is $23 \%$ (Adgaba, 1999) while the maximum acceptable moisture content of honey reported by the International Honey Commission is 20\% (Bogdanov, 2002). The low moisture content of the examined honey samples is important and affects keeping quality. Moulds and yeasts cause deterioration of the quality of honey when the moisture content is high, especially if it is $>19 \%$ (Costa et al., 1999). The moisture content of honey depends on various factors such as the harvesting season, the degree of maturity that honey reached in the hive, type of hive used, and environmental temperature. The moisture content of honey samples obtained from modern hives was significantly $(p<0.001)$ higher than honey collected from traditional hives (Tab. 2). The variation observed in moisture content among honey samples obtained from the two hive types may be due to the difference in bee-hive handling practiced by the beekeepers. The low moisture content of honey obtained from traditional hives may be associated with a hive type that allowed loss of moisture from honey by evaporation. No significant moisture content differences $(\mathrm{p}>0.05)$ were observed between honey samples obtained from the different locations (Tab. 3).

The ash content of the honey samples obtained from the study area ranged from $0.014-0.31 \mathrm{~g}$ with a mean value of 0.17 (Tab. 1). The mineral content of blossom honey ranges from 0.1 to $0.3 \%$ (Bogdanov, 2011). The average ash content of honey collected from traditional hives was numerically lower than the average ash content of honey samples collected from modern hives (Tab. 2); however, no significant difference $(\mathrm{p}>0.05)$ in ash content was observed between honey samples obtained from the two type of hives (Tab. 2) or among honey samples obtained from the different locations (Tab. 3). The ash content of all the analyzed honey samples fell within the $0.01-1.2 \%$ range reported by the Ethiopian Quality and Standards Authority (QSAE, 2005) and $0.6 \%$ maximum limit reported by the International Honey Commission (Bogdanov, 2002) for mineral content of honey. The mineral content of honey is related to the geographical and botanical origin of the honey. Mineral content is an important indicator of possible environmental pollution and an indicator of the soil types of the area (Anklam,

Table 2 .

Comparison of physicochemical properties of honey samples collected from modern and traditional hives in the Homesha district

\begin{tabular}{||c|c|c||}
\hline \multirow{2}{*}{ Parameters } & \multicolumn{2}{|c|}{ Hive type } \\
\cline { 2 - 3 } & $\begin{array}{c}\text { Modern } \\
(\mathrm{n}=10)\end{array}$ & $\begin{array}{c}\text { Traditional } \\
(\mathrm{n}=5)\end{array}$ \\
\cline { 2 - 3 } & Mean $\pm \mathrm{SD}$ & Mean $\pm \mathrm{SD}$ \\
\hline Moisture $(\%$ by mass) & $17.2^{\mathrm{a}} \pm 0.86$ & $15.6^{\mathrm{b}} \pm 0.48$ \\
\hline Total ash $(\%$ by mass) & $0.16 \pm 0.07$ & $0.20 \pm 0.09$ \\
\hline Free acidity $(\mathrm{meq} / \mathrm{kg})$ & $25.76 \pm 8.30$ & $24.96 \pm 8.20$ \\
\hline $\mathrm{pH}$ & $4.02 \pm 0.23$ & $3.88 \pm 0.37$ \\
\hline $\mathrm{HMF}(\mathrm{mg} / \mathrm{kg})$ & $2.32^{\mathrm{a}} \pm 0.60$ & $2.4^{\mathrm{b}} \pm 0.49$ \\
\hline Water-insoluble solids (g/100 g) & $0.02^{\mathrm{a}} \pm 0.02$ & $0.13^{\mathrm{b}} \pm 0.13$ \\
\hline Reducing sugars $\%$ by mass) & $65.8 \pm 3.47$ & $63.9 \pm 2.02$ \\
\hline Sucrose $(\%$ by mass) & $5.4 \pm 0.61$ & $5.3 \pm 0.68$ \\
\hline \hline
\end{tabular}

$\mathrm{HMF}=$ hydroxymethylfurfural; $\mathrm{n}=$ number of samples; means followed by different superscript letters in a row are significantly different $(\mathrm{p}<0.05)$; *moisture content was significantly different at $\mathrm{p}<0.001$; $\mathrm{SD}=$ standard deviation 
1998). Rodriguez-Otero et al. (1994) suggested the ash content of honey depends on the material contained in the pollen collected by the bees during foraging on the flora.

The free acidity level of honey samples analyzed in the present study, ranged from 18.01 to $36.54 \mathrm{meq} / \mathrm{kg}$ with a mean value of $23.9 \mathrm{meq} / \mathrm{kg}$ ) (Tab. 1). The acidity of honey samples obtained from the two hive types (Tab. 2) and from the different locations (Tab. 3) did not show significant differences ( $p>0.05)$. None of the samples exceeded the honey acidity limit suggested by national (40 meq $/ \mathrm{kg})$ (Adg a ba , 1999) and international standards $(50 \mathrm{meq} / \mathrm{kg})$ (Bogdanov, 2002). Such results indicate the freshness of the honey samples and absence of unwanted fermentation in the analyzed honey samples. The acidity of honey is important for taste (Bogdanov, 2011). The main organic acid found in honey is gluconic acid. Honey also contains minor components such as formic, acetic, citric, lactic, maleic, malic, oxalic, pyroglutamic and succinic acids (Bogdanov, 2011).

Most honeys are acidic and have low $\mathrm{pH}$ values. The $\mathrm{pH}$ values of honey samples analyzed in the current study ranged from 3.52 to 4.46 with a mean value of 4.02 (Tab. 1). The mean $\mathrm{pH}$ value of the honey from the study area is inline with $\mathrm{pH}$ values reported earlier. The $\mathrm{pH}$ of honey should be between 3.2 and 4.5 according to Bogdanov et al. (1999). No significant differences $(\mathrm{p}>0.05)$ in $\mathrm{pH}$ were observed between honey samples obtained from traditional and modern hives (Tab. 2) and also between honey samples obtained from the different locations (Tab. 3).

The hydroxymethylfurfural (HMF) content of the honey samples analyzed in this study ranged from 0.5 to $3.2 \mathrm{mg} / \mathrm{kg}$ with a mean value of $1.8 \mathrm{mg} / \mathrm{kg}$ (Tab. 1). The average HMF content of honey collected from traditional hives was significantly higher $(p<0.05)$ than that from modern hives (Tab. 2). The amount of HMF in honey is one of the important indicators of honey quality. In fresh honey, HMF is present only in trace amounts and its concentration increases with storage and prolonged heating of honey (Bogdanov, 2011). Diez (2002) reported that the hydroxymethylfurfural content of honey is an indicator of its freshness. Such results suggest that in the present study, honey samples obtained from traditional hives might have been kept for a longer period of time after harvest than honey from modern hives. Nonetheless, no significant difference in HMF content was observed between honey samples obtained from different locations (Tab. 3). The overall mean HMF content of honey from the study area is by far lower than the national average $(32.4 \mathrm{mg} / \mathrm{kg})$ (Adgaba, 1999).

Table 3 .

Comparison of physicochemical properties (mean $\pm \mathrm{SD}$ ) of honey samples obtained from three agro-ecologies and the market in the Homesha district

\begin{tabular}{||c|c|c|c|c||}
\hline \hline \multirow{2}{*}{ Parameters } & \multicolumn{4}{|c||}{ Location } \\
\cline { 2 - 5 } & $\begin{array}{c}\text { Natural vegetation } \\
\text { dominated area } \\
(\mathrm{n}=6)\end{array}$ & $\begin{array}{c}\text { Mango dominated } \\
\text { area } \\
(\mathrm{n}=6)\end{array}$ & $\begin{array}{c}\text { Crop dominated } \\
\text { area } \\
(\mathrm{n}=3)\end{array}$ & $\begin{array}{c}\text { Market } \\
\text { honey } \\
(\mathrm{n}=5)\end{array}$ \\
\hline Moisture (\% by mass) & $16.7 \pm 1.16$ & $16.4 \pm 1.05$ & $17.3 \pm 1.02$ & $15.7 \pm 0.72$ \\
\hline Total ash (\% by mass) & $0.17 \pm 0.07$ & $0.13 \pm 0.08$ & $0.25 \pm 0.06$ & $0.15 \pm 0.02$ \\
\hline Acidity (meq/kg) & $27.3 \pm 9.07$ & $21.8 \pm 7.22$ & $29.3 \pm 3.04$ & $19.4 \pm 1.72$ \\
\hline $\mathrm{pH}$ & $4.1 \pm 0.32$ & $4.0 \pm 0.29$ & $3.8 \pm 0.13$ & $4.2 \pm 0.12$ \\
\hline $\mathrm{HMF}(\mathrm{mg} / \mathrm{kg})$ & $1.7 \pm 0.50$ & $1.34 \pm 0.99$ & $2.1 \pm 0.81$ & $2.34 \pm 1.02$ \\
\hline Water-insoluble solids (g/100 g) & $0.07 \pm 0.11$ & $0.05 \pm 0.09$ & $0.03 \pm 0.04$ & $0.096 \pm 0.22$ \\
\hline Reducing sugars $(\%$ by mass) & $65.4 \pm 3.32$ & $63.2 \pm 1.59$ & $68.7 \pm 2.13$ & $64.4 \pm 2.90$ \\
\hline Sucrose (\% by mass) & $5.43^{\mathrm{a}} \pm 0.51$ & $5.58^{\mathrm{a}} \pm 0.85$ & $5.0^{\mathrm{a}} \pm 0.15$ & $8.18^{\mathrm{b}} \pm 2.30$ \\
\hline
\end{tabular}

HMF $=$ hydroxymethylfurfural; $\mathrm{n}=$ number of samples; means followed by different superscript letters in a row are significantly different $(\mathrm{p}<0.05) ; \mathrm{SD}=$ standard deviation; $\mathrm{SD}=$ standard deviation. 
The low HMF content of honey produced in the study area indicates its freshness and the good honey handling practice of the area.

The water-insoluble solids content of honey samples analyzed in the present study ranged from 0.01 to $0.46 \mathrm{~g} / \mathrm{kg}$ with a mean value of 0.09 (Tab. 1). The mean waterinsoluble solids content of honey obtained from traditional hives was significantly higher $(\mathrm{p}<0.05)$ than that obtained from modern hives (Tab. 2). This variation may be due to difference in harvesting practices and the storage condition of honey from the two types of hives. The amount of waterinsoluble solids content of honey samples obtained from different locations did not show significant differences $(\mathrm{p}>0.05)$ (Tab. 3). Honey's water-insoluble matter (solids) includes wax, pollen, honey-comb and particles of debris. Water-insoluble matter of honey is used as a criterion of honey's cleanliness. The maximum acceptable amount of water-insoluble matter in honey is $0.1 \%$ as reported by QSAE (2005). According to Bogdanov (2002), even $0.1 \%$ of water-insoluble matter in honey is considered high. The high water-insoluble solids content of honey obtained from traditional hives suggests the poor hygienic and harvesting conditions of honey from traditional hives in the study area.

The content of reducing sugar in the analyzed honey samples ranged from 62.0 to 71.0 with a mean value of $65 \%$ (Tab. 1). No significant difference $(p>0.05)$ in the content of reducing sugar was observed between honey samples obtained from modern and traditional hives (Tab. 2) and the same was true for honey samples obtained from different locations (Tab. 3). The content of reducing sugar in the analyzed honey samples of the current study falls within the national standard $(65 \%)$ for content of reducing sugar in honey. Sugars are the main constituents of honey comprising about $95 \%$ of honey dry weight (Bogdanov, 2011). Reducing and non-reducing sugars together, account for $85-95 \%$ of the carbohydrate in honey; the amount depends on the source of honey (Cavian, 2002). The sugars of honey are responsible for many of the physicochemical properties such as viscosity, hygroscopic and granulation characteristics of honey.

No significant differences $(p>0.05)$ in the sucrose content was observed between honey samples obtained from modern and traditional hives (Tab. 2). However, the average sucrose content $(8.1 \%)$ of honey samples purchased from the market, was significantly $(p<0.05)$ higher than sucrose contents of honey samples collected from the three agro-ecologies (Tab. 3). The high sucrose content observed in honey samples purchased from the market suggests an addition of sugar in the honey. Added sugar in honey can be detected by measuring its sucrose content. The sucrose content of honey mainly depends on the botanical origin of nectar and according to International Regulatory Standards it should not exceed 5\% (g/100g). Exceptions include some kinds of honey from nectar with a naturally higher content of this compound - false accacia (Robinia pseudoaccacia), alfalfa (Medicago sativa), Banksia (Banksia menzes), French honeysuckle (Hedysarum), red gum (Eucaluptus camandulensis), leatherwood (Eucrypis lucida, Eucryphia milliganii), lavender (Lavendula spp.), and borage (Borago officinalis) (Codex Alimentarius 2001, Council Directive, 2002). The maximum sucrose content criterion set at 5\% helps but little to assess the authenticity and the degree of change in the product (RybakChmielewska and Szczęsna, 2003; Rybak-Chmielewska et al., 2006). An erlose content of several percent may be a characteristic trait and may provide a good indicator of honey which has been changed by sucrose inverts used by beekeepers for feeding bees during nectar flow (RybakChmielewska et al., 2006). 


\section{CONCLUSION}

Except for sucrose content, no significant differences $(p>0.05)$ were observed between honey samples collected from the different locations, for the honey quality parameters considered. Hive type significantly $(p<0.05) \quad$ influenced the moisture, hydroxymethylfurfural and water-insoluble solids content of honey samples. However, hive type did not affect the $\mathrm{pH}$, acidity, ash, reducing sugars and sucrose content of the honey samples. All the quality parameters analyzed for honey produced in the Homesha district comply with both national and international standards. This suggests that honey produced in the study area is generally of good quality and thus can meet the demands of national and international markets for honey.

\section{ACKNOWLEDGEMENTS}

This study was funded by the Rural Capacity Building Project of the Ministry of Agriculture and Rural Development of Ethiopia.

\section{REFERENCES}

Adgaba N. (1999) - Quality state and grading of Ethiopian honey. In Proceedings of the First National Conference of Ethiopian Beekeepers Association, Ethiopia- Addis Ababa, 7-8 June, 1999. pp. 74-82.

Adgaba N. (2007) - Atlas of pollen grains of major honeybee flora of Ethiopia, Holetta Bee Research Centre, Holetta, Ethiopia.

Anklam E. (1998) - A review of the analytical method to determine the geographical and botanical origin of honey. Food Chem., 63: 549-562.

Bogdanov S. (2002) - Harmonized methods of the International Honey Commission, [Online] http://www.apis.admin.ch/english/ host/pdf/honey/HMF_abstract.pdf (accessed on 23 October 2011).

Bogdanov S. (2011) - The honey book, Bee Product Science, Switzerland, [Online] http://www.bee-hexagon.net (accessed on 13 September 2011).
Bogdanov S., Lullmann C., Mossel B. L., D'Arcy B. R., Russmann H., Vorwohl G., Oddo L., Sabatini A. G., Marcazzan G. L., Piro R., Flamini C., Morlot M., Lheretier J., Borneck R., Marioleas P., Tsigouri A., Kerkvliet J., Ortiz A., Ivanov T., Vit P., Martin P., von der Ohe W. (1999) - Honey quality, methods of analysis and international regulatory standards: review of the work of the International Honey Commission. Mitt. Lebensm. Hyg., 90: 108-125.

Cavian M. (2002) - Evolution of glucose and fructose in one year: influence of induced granulation. Food Chem., 78: 157-161.

Codex Alimentarius Commission (2001). 24 $4^{\text {th }}$ Session, July 2001, adopting the draft revised standard for honey. Alinorm 01/25, Appendix II: 22 - 24. Cotte J.F., Casabianca H.,

Council Directive 2001/110/EC of 20 December 2001 relating to honey (2002) - Official Journal of European Communities L., 10: 47-52.

Costa L. S. M., Albuquerque M. L. S., Trugo L. C., Quinteiro L. M. C., Barth O. M., Ribeiro M., De Maria C. A. B.(1999) Determination of non-volatile compounds of different botanical origin Brazilian honeys. Food Chem., 65: 347-352.

Diez M. (2002) - Characterization of uniflora honey by their physical characteristics. Food Chem., 79: 373-379.

Jones S. L., Jones, H. R., Thrasyvoulou A. (2011) - Disseminating research about bee products. A review of articles published in the Journal of Apicultural Research over the past fifty years. Journal of ApiProduct and ApiMedical Science, 3(3): 105-116.

Lane J., Eynon L. (1923) - Determination of reducing sugar by means of Fehling's solution with methylene blue as internal indicator. J. Soc. Chem. India, 42: 32-36.

MoARD (2007) - Livestock development master plan study phase I report - data collection and analysis, Volume N- apiculture, Ministry of Agriculture and Rural Development (MoARD), Addis Ababa, Ethiopia. 
Negera E. (2005) - Survey on honey production system in West Shoa Zone, Holetta Bee Research Center, Holetta, Ethiopia.

Oddo L. P., Bogdanov S. (2004) Determination of honey botanical origin: problems and issues, Apidologie, 35: 2-3.

Pearson D. (1971) - The chemical analysis of foods, $6^{\text {th }}$ ed., Chemical Publishing Company Inc., New York, pp. 123-126.

Persano Oddo L., Piro R. (2004) - Main European unifloral honeys: descriptive sheets. Apidologie, 35: 38-81.

QS AE (2005) - Honey specification: Ethiopian standard, ES 1202: 2005. Quality and Standards Authority of Ethiopia (QSAE), Addis Ababa, Ethiopia, pp. 1-17.

Rodriguez-Otero J. L., Paseiro P., Simal J., Cepeda A. (1994) - Mineral content of the honeys produced in Galicia (North-West Spain). Food Chem., 49: 169-171.

Rybak-Chmielewska H., Szczęsna T. (2003) - Determination of saccharides In multifloral honey by means of HPLC. J. Apic. Sci., 47(2): 93-101.

Rybak-Chmielewska H., Szczęsna T., Bieńkowska M.(2006)-Gaschromatography (GC) study of su gar composition in honey and winter stores processed by bees from sucrose syrops. J. Apic. Sci., 50(2): 147-155.

SAS. (2002) - SAS/STAT users' guide, version 9, Statistical Analysis System (SAS) Institute Inc., Cary NC, USA.

Szczęsna T., Rybak-Chmielewska H., Waś E., Kachaniuk K., Teper D. (2011) - Characteristics of Polish unifloral honeys. I. Rape honey (Brassica napus L. var. Oleifera Metzger). J. Apic. Sci., 55(1): 111-119.

Waś E., Rybak-Chmielewska H., Szczęsna T., Kachaniuk K., Teper D. (2011a) - Characteristics of Polish unifloral honeys. II. Lime honey (Tilia Spp.). J. Apic. Sci., 55(1): 121-127.

Waś E., Rybak-Chmielewska H., Szczęsna T., Kachaniuk K., Teper D. (2011b) - Characteristics of Polish unifloral honeys. III. Heather honey (Calluna vulgaris L.). J. Apic. Sci., 55(1): 129135.

White J. W., Riethof M., Subers M., Kushnir L. (1962) - Composition of American honey. USDA Tech. Bull., 1261: $1-124$.

\title{
WŁAŚCIWOŚCI FIZYKOCHEMICZNE MIODU PRODUKOWANEGO W REJONIE HOMESIA, ZACHODNIA ETIOPIA
}

\author{
Gobessa S., Seifu E., Bezabih A. \\ S t r e s z c z e n i e
}

Celem badań była charakterystyka fizykochemiczna miodu produkowanego w rejonie Homesia, zachodniej Etiopii oraz ocena wpływu lokalizacji pasieki jak i typu ula na jakość miodu pozyskiwanego na tym obszarze. Zebrano łącznie 20 próbek miodu z czterech pasiek rejonu. Ogólna średnia $( \pm \mathrm{SD})$ zawartość cukrów redukujących, sacharozy, $\mathrm{pH}$, wody, popiołu, hydroksymetylofurfuralu, kwasowości oraz substancji stałych nierozpuszczalnych w wodzie w analizowanych próbach miodu były odpowiednio $65 \pm 3,02 \%, 6,1 \pm 3,4 \%, 4,02 \pm 0,26$, $16,4 \pm 1,07 \%, 0,17 \pm 0,07 \%, 1,8 \pm 0,24 \mathrm{mg} / \mathrm{kg}, 23,9 \pm 7,4 \mathrm{meq} / \mathrm{kg}$ oraz $0,09 \pm 0,14 \%$. Zawartość sacharozy w próbach miodu zakupionego była znacznie wyższa $(\mathrm{p}<0,05)$ niż zawartość sacharozy w próbach miodu zebranego w innych miejscach. Typ ula istotnie wpływał $(\mathrm{p}<0,05)$ na zawartość wody, HMF i zawartość substancji stałych nierozpuszczalnych w miodzie. Można stwierdzić, że miód produkowany w rejonie Homesia jest dobrej jakości i może sprostać wymaganiom rynku krajowego i międzynarodowego.

Słowa kluczowe: miód, skład chemiczny, właściwości fizyczne, jakość, Homesia, Etiopia. 